\title{
Salt Groundwater Intrusion in the Pleistocene Aquifer in the Southern Part of the Red River Delta, Vietnam
}

\author{
Hoang Van Hoan ${ }^{1, *}$, Flemming Larsen ${ }^{2}$, Nguyen Van Lam ${ }^{1}$, \\ Dang Duc Nhan ${ }^{3}$, Tran Thi Luu ${ }^{4}$, Pham Quy Nhan ${ }^{5}$ \\ ${ }^{1}$ Hanoi University of Mining and Geology, Duc Thang, North Tu Liem, Hanoi, Vietnam \\ ${ }^{2}$ Geological Survey of Denmark and Greenland, 10, Øster Voldgade, DK-1350 Copenhagen K, Denmark \\ ${ }^{3}$ Vietnam Association of Hydrogeology, Nghia Do, Cau Giay, Hanoi, Vietnam \\ ${ }^{4}$ Hanoi University of Science, 334 Nguyen Trai, Thanh Xuan, Hanoi, Vietnam \\ ${ }^{5}$ Hanoi University of Natural Resources and Environment, Phu Dien, North Tu Liem, Hanoi, Vietnam
}

Received 05 September 2017

Revised 16 March 2018; Accepted 21 March 2018

\begin{abstract}
Fresh groundwater was found in the Pleistocene aquifer in the southern part of the Red River Delta in 70's of last century. It is located mainly in the south of Nam Dinh province and small part in southeast of Ninh Binh province. The fresh-saline boundary seems to migrate southward recently and downsize the area of fresh groundwater. It is necessary to find out the mechanisms of salt intrusion into the zone of freshwater in order to mitigate the negative impacts to the quality of water supply. Based on the survey data of groundwater chemistry, transient electromagnetic sounding, borehole logging, drilling, and chemical analysis of pore water squeezed from the low permeable sediment in the study region, it was determined the current spatial distribution of saline water in the Pleistocene aquifer and in marine clay layers. By combining these data with the results from previous studies, this study has determined the mechanisms of the salt intrusion into the freshwater zone. It was found that salinity in the Pleistocene aquifer is generated from two main sources (1) Vertical salt intrusion from the upper marine clay layer which is controlled by the diffusion and density flow and (2) Horizontal saltwater incursion due to the high hydraulic gradient which is controlled by the convection and dispersion which was generated by over groundwater exploitation.
\end{abstract}

Keywords: Salt water, intrusion mechanism, Red River Delta.

\footnotetext{
* Corresponding author. Tel.: 84-983653229.

Email: hoanghoandctv@gmail.com
}

https://doi.org/10.25073/2588-1094/vnuees.4127 


\section{Introduction}

Coastal aquifers are normally affected by salt intrusion from the local seas. There are numbers of studies accessed the high salinity of groundwater in coastal aquifers worldwide [110]. The origin and extent of saline, brackish and fresh groundwater, in the Red River Delta (RRD), has been studied by [11-14]. While groundwater in the coastal area of the RRD was saline, there are fresh groundwater lens existed in the Pleistocene aquifer in the Nam Dinh region. This has also been mentioned in the previous works of [15-17]. In this study multi methods will be used to assess the distribution and sources of fresh and saline groundwater in the Pleistocene aquifer as well as mechanism of salt intrusion into freshwater lens in the Pleistocene aquifer in the southern part of the RRD.

\section{Methodology and data base of the study site}

\subsection{Geology}

The geological data was determined throughout borehole logs, which are collected from all of projects implemented in study site. The Southwest of RRD is covered by Quaternary sediments with thickness varies from $40-50 \mathrm{~m}$ in apex to $200 \mathrm{~m}$ in the centre of the study area [18-26]. According to [18, 19], the formation of Quaternary sediments was controlled by sea level change and could be divided into 5 cycles. The first two of these cycles were of lower to middle Pleistocene age and composed of coarse grained alluvial/fluvial deposits, followed by an upper Pleistocene cycle of fluvial deposits, which was grading upwards into deltaic-lacustrine swamp environment sediments. The fourth cycle was of lower to middle Holocene age composed of fine grained sands and clays formed in deltaic environments; the uppermost fifth cycle from the upper Holocene was dominated by coarsegrained deposits laid down in the delta plain and delta front environments. As results, in certain conditions, highstand or lowstand, the Pleistocene and Holocene aquifers and aquitards would be formed.

\subsection{Groundwater chemistry}

The depth of the filters is over 100 meters from the surface. Before taking samples, the stagnant water in the wells was completely flushed out till $\mathrm{pH}$ and temperature of water be unchanged. Around $100 \mathrm{ml}$ of groundwater from the wells were then sampled. The samples were first filtered through $0.45 \mu \mathrm{m}$ mesh filters then splited into two parts. One part was acidified with $\mathrm{HNO}_{3}$ to $\mathrm{pH} 1-2$ (PA grade, Merck supplier) and subject to the analysis for major cations, but another part was not acidified be used for the major anions analysis and total dissolved solids (TDS) concentration determination. Groundwater was sampled from 35 boreholes spreading almost througout the area of the Nam Dinh province. These boreholes are screened in the Pleistocene aquifer (Figure 1).

\subsection{Borehole logging}

Robinson Research Ltd equipment was used for the geophysical logging of the sediments for natural gamma radiation and formation electrical conductivities. Formation electrical conductivities were measured inside the PVC casings using a focused induction probe, which has a formation penetration depth of around $5 \mathrm{~m}$. The borehole logging measurement was conducted in the boreholes along the cross-section C-B (Figure 1). The length of the cross-section was about $20 \mathrm{~km}$. The output of this investigation will help to understand the distribution of saltwater in the clay layer via the resistivity values of formation. The borehole logging was carried out in the boreholes ND01 and ND02 (Figure 1).

\subsection{Porewater sampling and analysis}

The sediment samples were squeezed to separate porewater from the sediment for analysis for it's chemical and stable isotope 
composition. The completeness of the separation procedure was checked by gravimetry and it was better than $99 \%$. The number of porewater samples along the depths and other related information are listed in table 1 and table 2. Sediment samples were taken from the boreholes ND01 and ND02 (Figure 1).

\section{Distribution of fresh and saline groundwater/porewater in sediments}

\subsection{Spatial distribution of fresh and saline groundwater in the Pleistocene aquifer}

The distribution of fresh and saline groundwater in the Pleistocene aquifer was mapped based on the TDS content in samples taken from 35 boreholes (Figure 1). The data shows that fresh groundwater (TDS $<1 \mathrm{~g} / \mathrm{L}$ ) in the southern part of the RRD is available in the region from the East to the center while the brackish and saline groundwater presents in the
North, Southwest and Northeast (Figure 1). The TDS distribution in Pleistocene aquifer seem to increase gradually from borehole Q109a towards the North and reach to highest values in Northeast direction.

\subsection{The vertical salinity distribution}

The vertical salinity distribution was determined based on the results of the the induction $\log$ (conductivity of formation) of boreholes combined with the data of chemical composition (TDS) of pore water. Correlation between electrical conductivity and chloride and TDS concentration were closed with correlation coefficients $\left(\mathrm{R}^{2}\right)$ of 0.9558 and 0.9733 , respectively [16]. The high TDS concentrations in porewater were recorded from $20 \mathrm{~m}$ to $30 \mathrm{~m}$ depth ranging from $28 \mathrm{~g} / \mathrm{l}$ to $37 \mathrm{~g} / \mathrm{l}$, and it decreases from middle towards the top and the bottom of the Holocene marine clay layer (Figure 2).

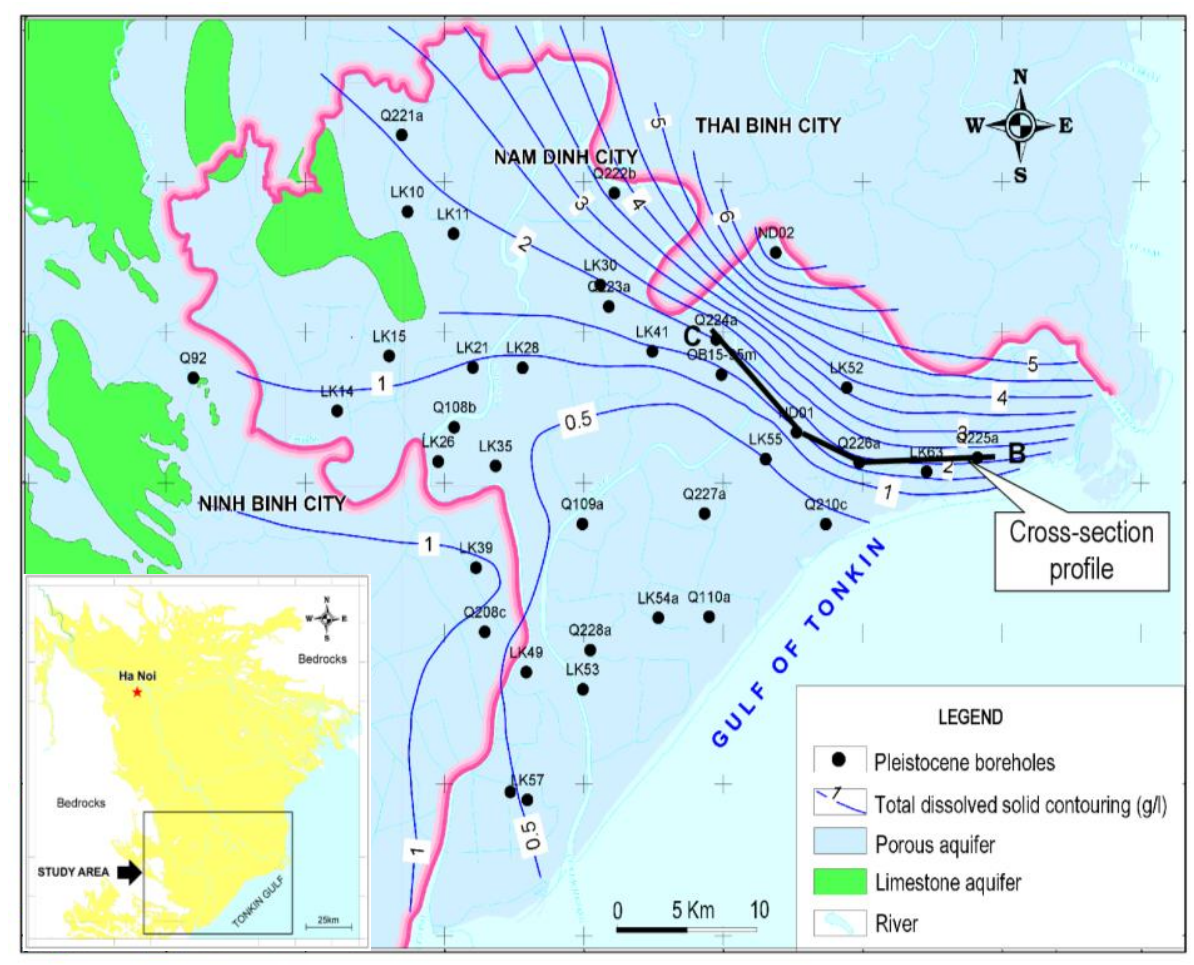

Figure 1. Distribution of TDS of groundwater in the Pleistocene aquifer [27]. 


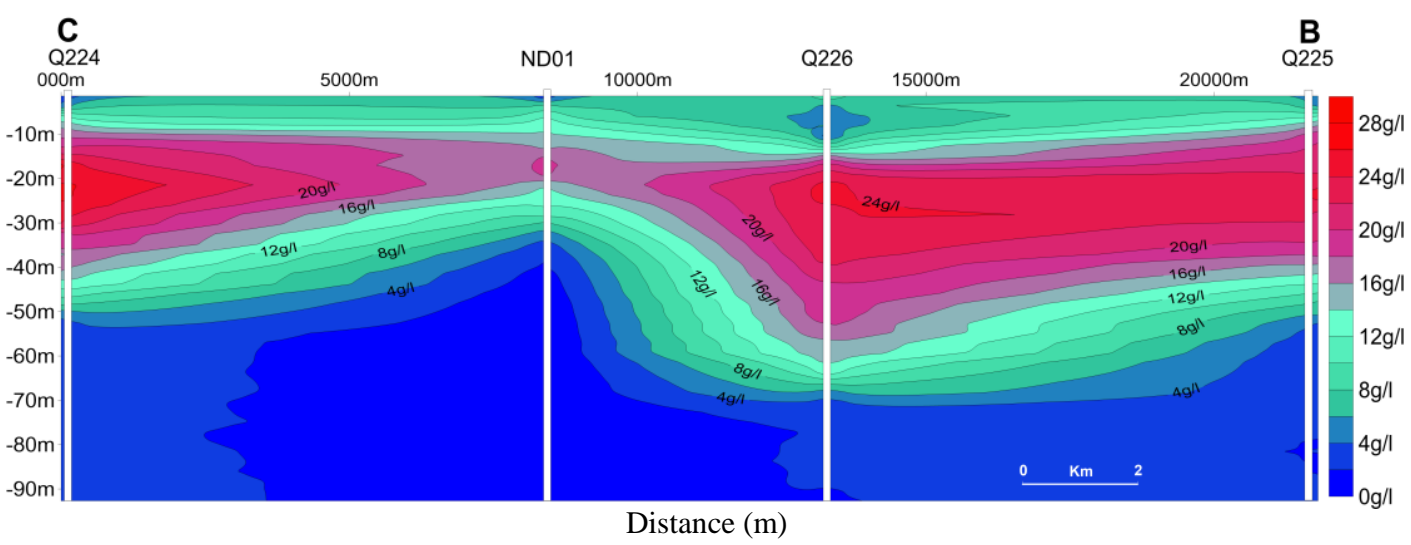

Figure 2. The vertical salinity distribution (TDS).

\section{Mechanism of saltwater intrusion into fresh water lens in the Pleistocene aquifer}

Based on the data of investigations using diverse techniques like borehole logging, drilling, pore water squeezing from sediment sample, and chemical analysis of the pore water, correlations between salinity in pore water and geophysical borehole parameters was established.

\subsection{The saltwater sources in the Pleistocene aquifer}

From the geographic of the study area, three sources of saltwater could be available in the Pleistocene aquifer as follows:

(1) Saltwater intrusion from the sea and river mouths;

(2) Saltwater migration from the pores of the aquifer sediment;

(3) Saltwater leakage from the Holocene marine clay.
Freshwater lens in Pleistocene aquifer contacts directly with the two later saltwater sources (number 2 and 3). In addition, the Holocene marine clay is also recharged by sea water when these two sources contact with each other. Therefore, in this study the effect of the two sources which directly contact with freshwater lens in Pleistocene aquifer was evaluated.

\subsection{Saltwater intrusion from Holocene marine clay}

The chemical and stable isotope compositions of pore water squeezed from the Holocene marine clay are shown in table 1 and table 2. Water in the borehole ND02, at the depth of $26.83 \mathrm{~m}$ has composition of oxygen-18 $\left(\delta^{18} \mathrm{O}\right)$ and deuterium $\left(\delta^{2} \mathrm{H}\right)$ to be $-1.02 \%$ and $8.51 \%$ (vs. VSMOW), respectively (Table 2). At the same time the concentrations of chloride and sodium, respectively, were $19,534.31 \mathrm{mg} / 1$ and $\left[\mathrm{Na}^{+}\right]=8,555.8 \mathrm{mg} / \mathrm{l}$ suggesting the marine origin of saline water at this monitoring point.

Table 1. Chemical and stable isotopes compositions of pore water in the borehole ND01 (see Figure 1 for the location)

\begin{tabular}{lllllll}
\hline Sample ID & $\begin{array}{l}\text { Depth } \\
(\mathrm{m})\end{array}$ & $\begin{array}{l}\delta^{18} \mathrm{O} \\
(\%)\end{array}$ & $\delta^{2} \mathrm{H}(\%)$ & $\begin{array}{l}\mathrm{Na}^{+} \\
(\mathrm{mg} / \mathrm{l})\end{array}$ & $\begin{array}{l}\mathrm{Cl}^{-} \\
(\mathrm{mg} / \mathrm{l})\end{array}$ \\
\hline 1 & ND01-2 & 6.23 & -3.86 & -30.21 & - & $5,251.05$ \\
2 & ND01-8 & 11.22 & -2.27 & -18.28 & $6,425.0$ & $13,859.72$ \\
3 & ND01-6 & 16.30 & -2.06 & -16.41 & $6,875.0$ & $15,286.43$ \\
4 & ND01-4 & 21.30 & -2.19 & -15.70 & $6,737.0$ & $12,587.11$ \\
\hline
\end{tabular}




\begin{tabular}{lllllll}
\hline Sample ID & $\begin{array}{l}\text { Depth } \\
(\mathrm{m})\end{array}$ & $\begin{array}{l}\delta^{18} \mathrm{O} \\
(\%)\end{array}$ & $\delta^{2} \mathrm{H}(\%)$ & $\begin{array}{l}\mathrm{Na}^{+} \\
(\mathrm{mg} / \mathrm{l})\end{array}$ & $\begin{array}{l}\mathrm{Cl}^{-} \\
(\mathrm{mg} / \mathrm{l})\end{array}$ \\
\hline 5 & ND01-11 & 26.80 & -2.95 & -22.73 & $4,511.0$ & $8,661.59$ \\
6 & ND01-10 & 31.33 & -4.88 & -34.60 & $2,510.0$ & $4,610.12$ \\
7 & ND01-7 & 36.50 & -4.98 & -38.89 & 861.5 & $2,119.26$ \\
8 & ND01-1 & 41.75 & -6.51 & -46.02 & 334.6 & 700.05 \\
9 & ND01-12 & 51.61 & -6.87 & -47.61 & 82.0 & 201.42 \\
10 & ND01-9 & 61.50 & -6.97 & -48.43 & 147.2 & 118.55 \\
11 & ND01-13 & 71.28 & -6.30 & -46.63 & 112.0 & - \\
12 & ND01-3 & 95.70 & -6.77 & -47.89 & 137.2 & 250.67 \\
\hline
\end{tabular}

Table 2. Chemical and stable isotopes compositions of pore water in the borehole ND02 (see Figure 1 for the location)

\begin{tabular}{lllllll}
\hline & Sample ID & $\begin{array}{l}\text { Depth } \\
(\mathrm{m})\end{array}$ & $\begin{array}{l}\delta^{18} \mathrm{O} \\
(\%)\end{array}$ & $\delta^{2} \mathrm{H}(\%)$ & $\begin{array}{l}\mathrm{Na}^{+} \\
(\mathrm{mg} / \mathrm{l})\end{array}$ & $\begin{array}{l}\mathrm{Cl}^{-} \\
(\mathrm{mg} / \mathrm{l})\end{array}$ \\
\hline 1 & ND02-17 & 4.03 & -8.63 & -61.50 & 18.7 & 18.99 \\
2 & ND02-18 & 7.78 & -7.18 & -48.66 & 28.4 & 8.99 \\
3 & ND02-19 & 11.72 & -7.54 & -52.46 & 63.3 & 44.12 \\
4 & ND02-16 & 16.72 & -3.63 & -28.15 & $6,296.0$ & $13,643.59$ \\
5 & ND02-20 & 21.84 & -1.26 & -9.62 & $8,226.0$ & $16,837.75$ \\
6 & ND02-21 & 26.83 & -1.02 & -8.51 & $8,555.8$ & $19,534.31$ \\
7 & ND02-22 & 31.83 & -1.31 & -8.70 & $9,970.0$ & $17,326.15$ \\
8 & ND02-23 & 36.83 & -1.61 & -12.26 & $6,530.0$ & $16,312.91$ \\
9 & ND02-24 & 41.16 & -2.02 & -15.48 & $6,874.0$ & $16,628.92$ \\
10 & ND02-25 & 46.67 & -2.82 & -21.94 & - & - \\
11 & ND02-26 & 51.72 & -1.30 & -9.99 & $4,483.0$ & $8,520.00$ \\
12 & ND02-5 & 66.14 & -5.27 & -41.31 & $2,031.0$ & $3,237.83$ \\
13 & ND02-28 & 72.61 & -6.17 & -44.40 & $1,865.0$ & $3,991.82$ \\
14 & ND02-29 & 77.28 & -6.00 & -43.91 & $1,573.5$ & $4,191.48$ \\
\hline
\end{tabular}

Figure 3 shows the high salinity in pore water squeezed from the Holocene marine clay layer. Relationship between $\delta^{18} \mathrm{O}$ and $\left[\mathrm{Cl}^{-}\right]$
(Figure 4) indicates that in the study region sea water tends to intrude into the Holocene marine clay layer and into the lower aquifer.

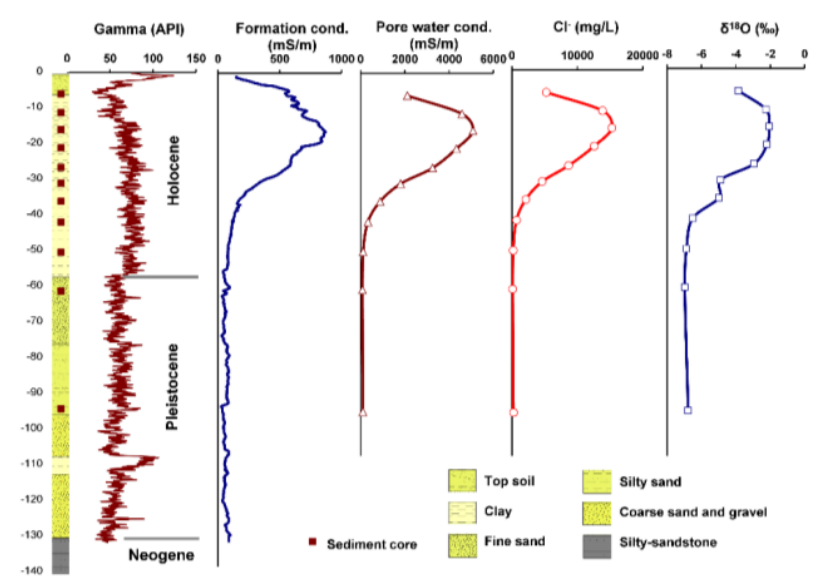

Figure 3. Distribution of electrical conductivity, $\left[\mathrm{Cl}^{-}\right], \delta^{18} \mathrm{O}$ of pore water along the depth and borehole logging at the ND01 location 


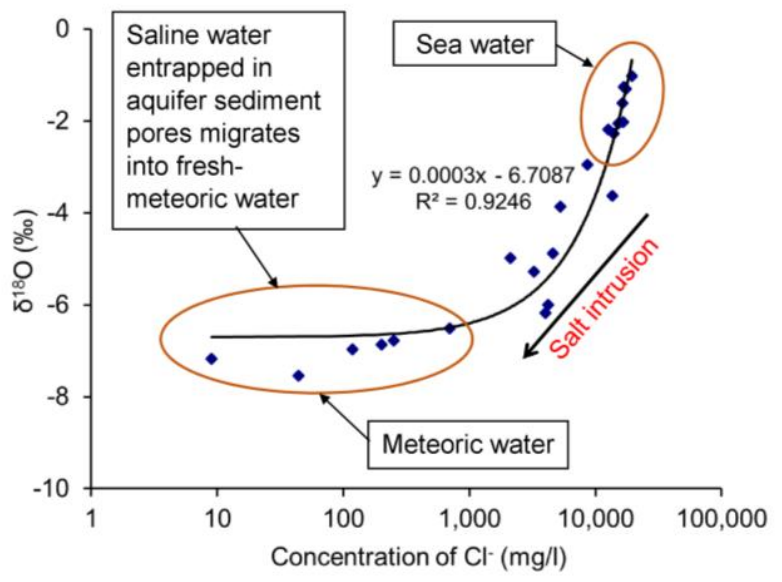

Figure 4. Relationship between $\delta^{18} \mathrm{O}$ and $\left[\mathrm{Cl}^{-}\right]$in water taken from the Pleistocene aquifer at different locations.

The data of geophysical boreholes (induction method) and chemical compositions of pore water as well as the relationship between the chemical compositions show that the electrical conductivity of aquifer sediment is controlled mainly by the salinity in pore water. The results of geophysical borehole survey can be used to determine the transport of salinity from pore water in the marine sediments to aquifer. Based on the correlation equation
(Figure 3), one can estimate the salinity in pore water over depth.

The data of stable isotopic compositions of pore water of the Holocene marine clay layer is a mixing of fresh water of meteoric origin in the Pleistocene aquifer with sea water (Figure 5). The distribution of $\delta^{2} \mathrm{H}$ and $\delta^{18} \mathrm{O}$ along the depth showed the downward decrease of contribution of sea water in the aquifer sediment [16] (Figure 4).

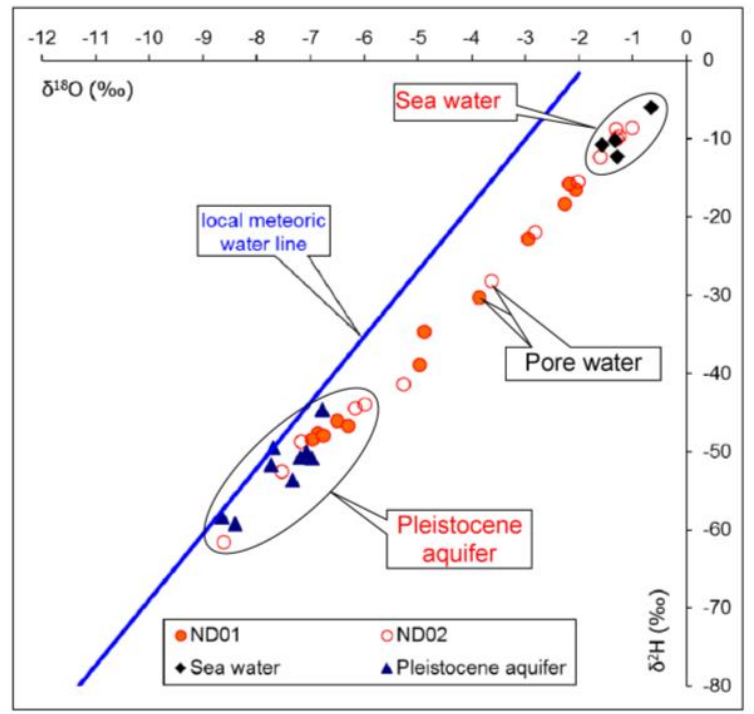

Figure 5. The composition of stable isotopes in pore water, sea water and water in the Pleistocene aquifer. 
The main factors influencing the solute transport from the Holocene marine clay layer are sediment compression, density flow and diffusion capability. In this study area, the compressing process is almost balanced among the sediment layers. The results of 1D model show that the density flow will occur in the sediments with $K \geq 10^{-7} \mathrm{~m} / \mathrm{s}$. The higher $K$ values, the more important the density flow is compared to the diffusion process. In the sediments with $\mathrm{K}<10^{-7} \mathrm{~m} / \mathrm{s}$, diffusion will be more important in solute transport than the density flow [16].

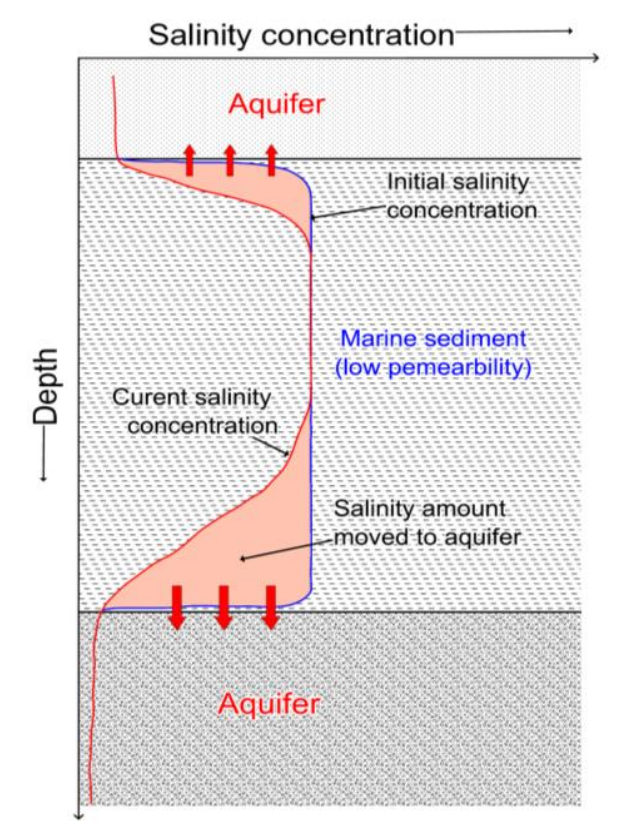

Figure 6. Conceptual model of saltwater intrusion from the Holocene marine sediment clay layer.

Results of this study showed that the diffusion and density flow are the two main processes controlling the solute transport in the Holocene marine clay layers in which the upper part is controlled by diffusion while the lower part is controlled by both diffusion and density flow. Figure 6 describes the current distribution of salinity in pore water of the clay layer and the amount of salinity that has been flushed out from the bottom and top clay layer. It is seen the less amount of salinity has been flushed out from the top part compared to that in the bottom because the latter part is under the influence of both two transport processes.

4.3. Saltwater intrusion into the freshwater lenses due to the difference of hydraulic head in the Pleistocene aquifer

Lithological composition of the Pleistocene aquifer

The results of geological surveys and particle analysis for the Pleistocene sediments showed that lithological compositions of those aquifer sediments are mainly fine to coarse sand mixed with gravel with the effective porosity ranging from 0.255 to 0.396 . The porosity of sediments was determined based on the particle analysis and semi- empirical equation which was given by Vukovic [27], semi-experimental.

$$
\begin{aligned}
& \mathrm{n}=0.255\left(1+0.83^{\mathrm{C}_{\mathrm{u}}}\right) \quad \text { With } \\
\mathrm{C}_{\mathrm{u}}=\mathrm{d}_{60} / \mathrm{d}_{10} & \\
& \text { Where: } \\
& n \text { - Porosity; } \\
& C_{u} \text { - The uniformity coefficient; } \\
& d_{60} \text { - The diameter of the particles at the }
\end{aligned}
$$
cumulative weight percentage of $60 \%$

$d_{10}$ - The diameter of the particles at the cumulative weight percentage of $10 \%$

Table 3 shows the porosity of sediment in the Pleistocene aquifer from different boreholes.

The hydrogeological parameters of the Pleistocene aquifer

Pleistocene aquifer is a high yield and productive aquifer with hydraulic conductivity varied from 10.5 to $39 \mathrm{~m} /$ day, transitivity ranged from 190.0 to $610.5 \mathrm{~m}^{2} /$ day and from 1,264 to $1,549 \mathrm{~m}^{2} /$ day that have been estimated from the pumping tests with 2 observation wells. 
Table 3. The porosity of the Pleistocene sediments

\begin{tabular}{|c|c|c|c|c|c|c|}
\hline & \multirow[t]{2}{*}{ Boreholes } & \multirow{2}{*}{$\begin{array}{l}\text { Depth } \\
(\mathrm{m})\end{array}$} & \multirow[t]{2}{*}{ Lithological composition } & \multicolumn{2}{|c|}{$\begin{array}{l}\text { Particle diameter } \\
(\mathrm{mm})\end{array}$} & \multirow[t]{2}{*}{ Porosity } \\
\hline & & & & $\mathrm{d} 10$ & $\mathrm{~d} 60$ & \\
\hline 1 & Q221a & 64 & Fine sand & 0.005 & 0.196 & 0.255 \\
\hline 2 & Q222b & 108 & $\begin{array}{l}\text { Medium to coarse sand } \\
\text { with gravel }\end{array}$ & 0.032 & 8.318 & 0.255 \\
\hline 3 & Q222b & 68 & $\begin{array}{l}\text { Fine to medium sand } \\
\text { with gravel }\end{array}$ & 0.046 & 0.221 & 0.359 \\
\hline 4 & $\mathrm{Q} 222 \mathrm{~b}$ & 85 & Medium sand with gravel & 0.076 & 0.240 & 0.396 \\
\hline 5 & Q223n & 107 & $\begin{array}{l}\text { Fine to medium sand } \\
\text { with gravel }\end{array}$ & 0.013 & 1.202 & 0.255 \\
\hline 6 & Q224a & 95 & Coarse sand with gravel & 1.514 & 8.710 & 0.342 \\
\hline 7 & Q225a & 108 & $\begin{array}{l}\text { Medium to coarse sand } \\
\text { with gravel }\end{array}$ & 0.145 & 0.537 & 0.383 \\
\hline 8 & Q226a & 91 & $\begin{array}{l}\text { Fine to medium sand } \\
\text { with gravel }\end{array}$ & 0.032 & 0.363 & 0.287 \\
\hline 9 & Q226n & 143 & Coarse sand with gravel & 0.045 & 0.380 & 0.307 \\
\hline 10 & Q227a & 112 & $\begin{array}{l}\text { Fine to medium sand } \\
\text { with gravel }\end{array}$ & 0.008 & 0.224 & 0.257 \\
\hline 11 & Q227a & 147 & $\begin{array}{l}\text { Fine to medium sand } \\
\text { with gravel }\end{array}$ & 0.042 & 0.537 & 0.278 \\
\hline 12 & Q228a & 114 & Medium sand with gravel & 0.030 & 0.309 & 0.291 \\
\hline 13 & $\mathrm{Q} 228 \mathrm{c}$ & 106 & Medium sand with gravel & 0.027 & 0.275 & 0.293 \\
\hline 14 & Q229n & 122 & Coarse sand with gravel & 0.033 & 0.269 & 0.311 \\
\hline 15 & Q229a & 80 & Coarse sand with gravel & 0.042 & 0.363 & 0.305 \\
\hline
\end{tabular}

Table 4. Hydraulic transitivity in the Pleistocene aquifer

\begin{tabular}{llllll}
\hline \multirow{2}{*}{ Boreholes } & \multicolumn{2}{l}{ Coordinates $(\mathrm{VN} 2000)$} & Depth $(\mathrm{m})$ & $\begin{array}{l}\text { Transitivity } \\
\left(\mathrm{m}^{2} / \text { day }\right)\end{array}$ \\
\cline { 3 - 5 } & $\mathrm{X}$ & $\mathrm{Y}$ & 80 & 425.4 \\
\hline 1 & LK15 & 2245442 & 611991 & 123 & $1,264.0$ \\
3 & LK28 & 2244652 & 621569 & 155 & 545.0 \\
4 & LK30 & 2250160 & 627146 & 141 & 581.3 \\
5 & LK54a & 2243337 & 644827 & 151 & 598.4 \\
6 & LK55 & 2228056 & 631301 & 170.5 & 410.4 \\
7 & LK26 & 2238601 & 639003 & 46 & 610.5 \\
8 & Q210B & 2238435 & 615511 & 120 & 190.0 \\
9 & LKXVI & 2234288 & 643328 & 110 & 358.0 \\
10 & Q227 & 2240391 & 641238 & 155.5 & $1,549.0$ \\
11 & ND01 & 2234979 & 634626 & 132 & $1,368.0$ \\
12 & ND02 & 2240372 & 641227 & 139 & $1,459.0$ \\
\hline
\end{tabular}




\section{Drawdown and flow direction in the Pleistocene aquifer}

Pleistocene aquifer in the Nam Dinh province is confined and recharged from the Triassic, Neogene and Holocene aquifers [28]. Groundwater level of the Pleistocene aquifer is about $2 \mathrm{~m}$ above sea level (asl) [29]. The consecutive monitoring data of national network from 1994 to 2014 showed the groundwater level in the Pleistocene aquifer was decreased with a rate of $0.5 \div 0.7 \mathrm{~m} /$ year (Figure 7).

The highest rate of water level drawdown is recorded at borehole Q109a located in Truc Phu, Truc Ninh district for which the Pleistocene aquifer is from the depth of $102 \mathrm{~m}$ to $132.8 \mathrm{~m}$ below the surface (Figure 7 ). In August of 1994, the groundwater level in that borehole was $+0.64 \mathrm{~m}$ asl but it declined down to $-10.37 \mathrm{~m}$ asl in July, 2013. The drawdown of the water level in the Pleistocene aquifer was attributed to the over rate of fresh water abstraction. The over rate of groundwater could lead the saline-freshwater boundary to migrate to the center of the depressing cone at the borehole Q109a with a rate of $0.029 \mathrm{~m} /$ day the Northwest, $0.042 \mathrm{~m} /$ day in the North, and $0.039 \mathrm{~m} /$ day in the Northeast (Fig. 8). This would result in the mixing of saltwater and freshwater in the Pleistocene aquifer due to the advection and dispersion. The intrusion rates are dependent on the hydraulic gradients from different directions of the aquifer.

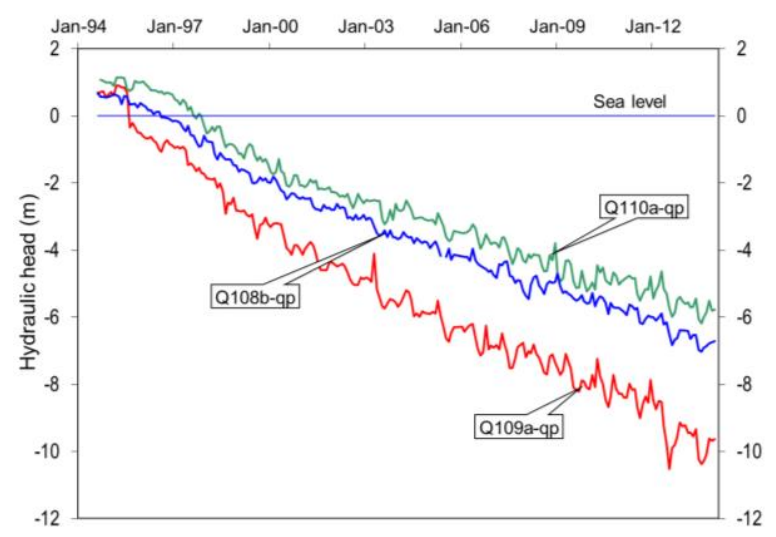

Figure 7. The decrease of water level in the Pleistocene aquifer from 1994 to 2014 recorded for the boreholes Q110a, Q108b and Q109a.

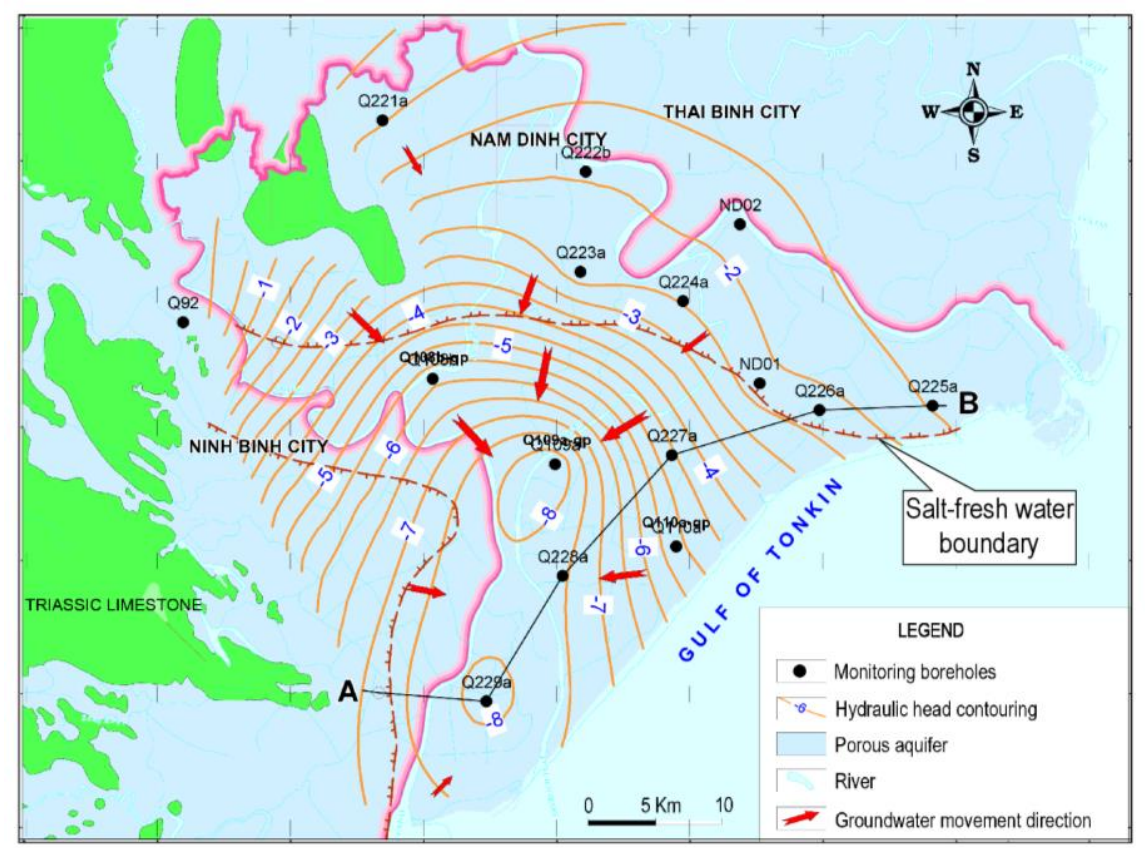

Figure 8. Groundwater flow direction in the Pleistocene aquifer due to the fresh water pumping from the borehole Q109a area (the South of the Nam Dinh province). 


\section{Conclusion}

The use of multi-hydrogeological techniques in study for saline and fresh groundwater lens distribution has revealed that saltwater intrusion in the Pleistocene aquifer in the southern part of the Red River Delta to occur due to:
- Vertical saltwater leakage from upper Holocene marine sediments that was controlled by the diffusion and density flow.

- Horizontal saltwater intrusion ion due to high hydraulic gradient generated by over groundwater exploitation.

A conceptual model described the abovementioned mechanisms of salt intrusion in the study area could be drawn as follows (Figure 9).

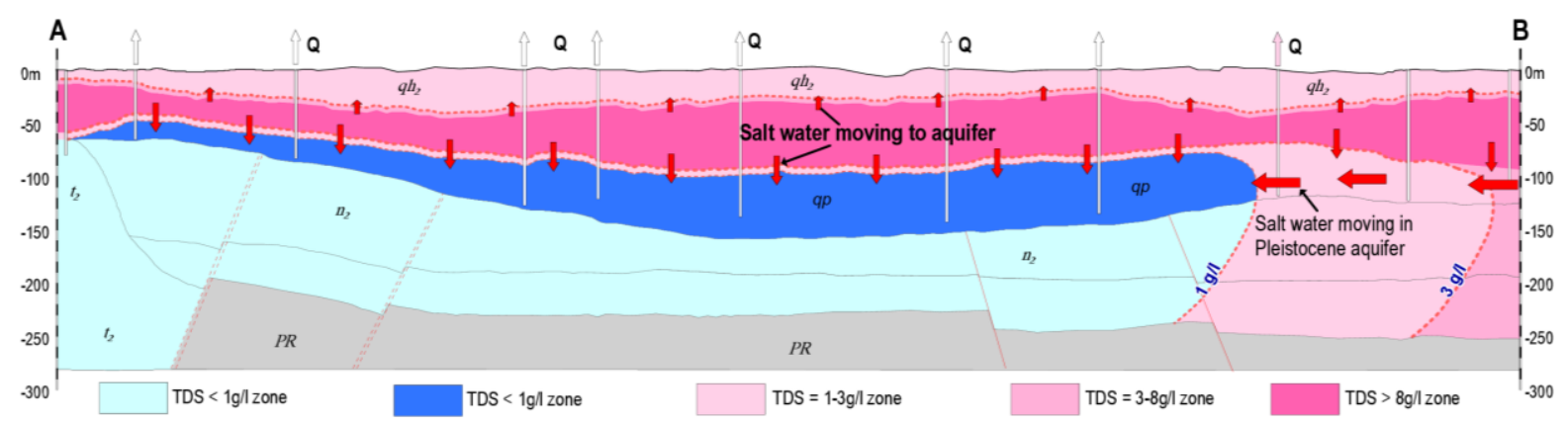

Figure 9. The concept model described the mechanism of salt intrusion in the Pleistocene aquifer. The figure was drawn along the cross-section $\mathrm{AB}$ (Figure 8)

It is recommended that a better management policy for groundwater exploitation in the southern part of the Red River Delta should be considered to have sustainable and high quality groundwater resource in that area, especially when the sea level is raising due to the climate change.

\section{Acknowledgements}

This research is funded by Vietnam National Foundation for Science and Technology Development (NAFOSTED) under grant number 105.99-2014.19.

\section{References}

[1] Akouvi A, Dray M, Violette S, and de Marsily G, Zuppi GM (2008), "The sedimentary coastal basin of Togo: example of a multilayered aquifer still influenced by a paleo-sea water intrusion", Hydrogeol J 16:419-436.
[2] Antonelli M, Mollema P, Giambastiani K, Bishop K, Caruso L, Minchio A, Pelligrini L, Sabia M, Ulazzi E, Gabbianelli G (2008), "Saltwater intrusion in the coastal aquifer of the southern Po Plain, Italy", Hydrogeol J 16:1541-1556.

[3] Custodio E (2010) Costal aquifers of Europe: an overview. Hydrogeol J 18:269-280.

[4] White I, Falkland T (2010) Management of freshwater lenses on small Pacific islands. Hydrogeol J 18:227-246.

[5] Gossel W, Sefelnasr A, Wysick P (2010) "Modelling of paleo- saltwater intrusion in the northern part of the Nubian Aquifer System, Northeast Africa", Hydrogeol J 18:1447-1463.

[6] Steyl G, Dennis I (2010) Review of coastal-area aquifers in Africa. Hydrogeol J 18:217-225.

[7] Zhang Q, Volker RE, Lockington DA (2004), "Numerical investiga - tion of sea water intrusion at Gooburrum, Bundaberg, Queensland", Australia, Hydrogeol J 1:674-687.

[8] Werner AD (2010) A review of sea water intrusion and its management in Australia. Hydrogeol J 18:281-285. 
[9] Barlow P, Reichard EG (2010) Saltwater intrusion in coastal regions of North America. Hydrogeol $\mathrm{J}$ 18:247-260.

[10] Bocanegra E, Silva GCD, Custodio E, Manzona M, Montenegro S (2010) State of knowledge of coastal aquifers management in South America. Hydrogeol J 18:261-267.

[11] Nhan Quy Pham (2000), "The fomation and potential of groundwater in Quaternary sediments in the Red River Delta", Doctoral Desertation, Vietnam National University, 126 pg (in Vietnamese).

[12] Ha Nguyen Thi (2005). Geochemistry of groundwater in Quaternary sediments in the Red River Delta and its importance to water supply. Doctoral Desertation, Vietnam National University, 159 pg (in Vietnamese).

[13] Luu T. Tran, Flemming Larsen, Nhan Q. Pham, Anders V. Christiansen, Nghi Tran, Hung V. Vu, Long V. Tran, Hoan V. Hoang, and Klaus Hinsby, 2012,"Origin and Extent of Fresh Groundwater, Saline Paleowaters and recent Saltwater Intrusion in Red River Flood Plain Aquifers, Vietnam", Hydrogeology Journal 20, 1295-1313.

[14] Thuy Nguyen Thanh et. al (2015), "Identification of spatio-seasonal hydrogeochemical characteristics of the unconfined groundwater in the Red River Delta, Vietnam", Applied geochemistry 63: 10-21.

[15] Frank Wagner, Đang Tran Trung, Hoang Dai Phuc, Falk Lindenmaier (2011), "Assessment of Groundwater Resources in Nam Dinh Province", Final Technical Report of Project - Improvement of Groundwater Protection in Vietnam, Part A.

[16] Hoang Van Hoan, Pham Quy Nhan, Flemming Larsen, Nguyen The Chuyen, 2014. Controlling factors to the distribution of salinity of porewater in Quaternary marine sediments in Nam Dinh area. Journal of Earth Sciences 36 (2) 6-2014, pp 139-148 (in Vietnamese).

[17] Nhan Quy Pham, Luu Thi Tran, Flemming Larsen, Christoph Gerber, Roland Purtschert, Canh Van Doan, 2015, "Groundwater recharge for Pleistocene aquifer in the Southwest of Red River Delta, Vietnam", Proceeding of the International Conference on Geology, Geotechnology, and Mineral Resources of INDOCHINA, November 23-24, 2015, Thailand.

[18] Tran Nghi, Ngo QT, Do TVT, Nguyen DM, Nguyen VV (1991), "Quaternary sedimentation of the principal deltas of Vietnam", J SE Asian Earth Sci 6:103-110.
[19] Lam Dinh Doan (2003), "The Evolution of Holocene sediments in the Red River Delta", Doctoral Desertation, Vietnam National Library, $129 \mathrm{pg}$.

[20] Tanabe S, Saito Y, Quang LV, Hanebuth TJJ, Quang LN, Kitamura A (2006), "Holocene evolution of the Song Hong (Red River) delta system, northern Vietnam".

[21] Mathers S, Zalasiewicz J (1999), "Holocene sedimentary architecture of the Red River Delta, Vietnam", J Coast Res 15:314-325 ediments in the Red River Delta", Doctoral Desertation, Vietnam National University, 126 pg (in Vietnamese).

[22] Lam Dinh Doan, Boyd WE (2003), "Holocene costal stratigraphy and the sedimentary development of the Hai Phong area of the Bac Bo plain (Red River delta), Vietnam", Aust Geogr 34:177-194.

[23] Tanabe S, Hori K, Saito Y, Haruyama S, Le QD, Sato Y, Hiraide S (2003a), "Sedimentary facies and radiocarbon dates of the Nam Dinh-1 core from the Song Hong (Red River) delta, Vietnam", J Asian Earth Sci 21:503-513.

[24] Tanabe S, Hori K, Saito Y, Haruyama S, Van PV, Kitamura A (2003b), "Song Hong (Red River) delta evolution related to millennium-scale Holocene sea-level changes", Quat Sci Rev 22:2345-2361.

[25] Hori K, Tanabe S, Saito Y, Haruvama S, Nguyen V, Kitamura A (2004), "Delta initiation and Holocene sea-level change: example from the Song Hong (Red River) delta, Vietnam", Sediment Geol 164:237-249.

[26] Funabiki S, Nguyen VQ, Viet PH, Dinh HT (2007), "Holocene delta plain development in the Song Hong (Red River) delta, Vietnam", J Asian Earth Sci 30:518-529.

[27] Vukovic, M., Soro, A., 1992. Determination of Hydraulic Conductivity of Porous Media From Grain-size Composition. Water Resources Publications, Littleton, 83 pp., Colorado.

[28] Hoang Van Hoan, Pham Quy Nhan, Flemming Larsen, Anders V. Christiansen, Kieu Duy Thong, Tran Vu Long, 2013. Saline groundwater mapping in estuary-coastal area, Nam Định Province by transient electromagnetic method. Journal of the Geological series A, No. 334, 3-4 / 2013, pp 5667 (in Vietnamese).

[29] Cao Xuan Xuyen (1978), Hydrogeological map of Hanoi - Hai Phong - Nam Dinh area. Scale 1: 200,000, Department of Geology and Minerals of Vietnam. 


\title{
Xâm nhập mặn nước dưới đất trong tầng chứa nước Pleistocen phía nam đồng bằng Sông Hồng, Việt Nam
}

\author{
Hoàng Văn Hoan ${ }^{1}$, Flemming Larsen ${ }^{2}$, Nguyễn Văn Lâm ${ }^{1}$, \\ Đặng Đức Nhận ${ }^{3}$, Trần Thị Lựu ${ }^{4}$, Phạm Quý Nhân ${ }^{5}$ \\ ${ }^{I}$ Trường Đại học Mỏ - Địa chất, phường Đức Thắng, Bắc Tù Liêm, Hà Nội, Việt Nam \\ ${ }^{2}$ Cuc Địa chất Đan Mạch, 10, Øster Voldgade, DK-1350 Copenhagen K, Denmark \\ ${ }^{3}$ Hội Địa chất thủy văn Việt Nam, Nghĩa Đô, Cầu Giấy, Hà Nội, Việt Nam \\ ${ }^{4}$ Trương Đại học Khoa học Tự nhiên Hà Nội, 334 Nguyễn Trãi, Thanh Xuân, Hà Nội, Việt Nam \\ ${ }^{5}$ Truờng Đại học Tài nguyên và Môi trường Hà Nội, Phú Diễn, Bắc Tù Liêm, Hà Nội, Việt Nam
}

Tóm tắt: Nước dưới đất nhạt đã được tìm thấy ở phía nam của đồng bằng sông Hồng, trong tầng chứa nước Pleistocen vào những năm 70 của thế kỷ trước, chủ yếu nằm ở phía nam của tỉnh Nam Định và một phần nhỏ phía đông nam tỉnh Ninh Bình. Trong những năm gần đây, ranh giới mặn nhạt di chuyển về phía nam và làm giảm diện tích nước phân bố nước nhạt. Việc xác định cơ chế xâm nhập mặn nhằm hạn chế tác động tiêu cực đến chất lượng cung cấp nước cho nhân dân địa phương là hết sức cần thiết và cấp bách. Trên cơ sở số liệu điều tra khảo sát thủy địa hóa, số liệu khảo sát địa vật lý (phương pháp trường chuyển và karota), kểt quả phân tích thành phần hóa học nước lỗ rỗng được chiết ép từ lớp trầm tích thấm nước yếu trong vùng nghiên cứu, đã xác định sự phân bố không gian hiện tại của nước mặn trong tầng chứa nước Pleistocene và trong lớp thấm nước yếu nguồn gốc biển. Việc kết hợp những kết quả nghiên cứu trên với các kết quả nghiên cứu trước đây, đã xác định cơ chế xâm nhập mặn nước dưới đất trong tầng chứa nước Pleistocen trong vùng nghiên cứu. Kết quả nghiên cứu cho thấy, nước mặn xâm nhập vào thấu kính nước nhạt trong tầng chứa nước Pleistocen bởi hai nguồn chính: (1) nước mặn xâm nhập từ lớp sét nguồn gốc biển phủ bên trên tầng chứa nước Pleistocen qua quá trình khuếch tán và phân dị trọng lực và (2) nước mặn trong cùng tầng chứa nước Pleistocen do chênh lệch áp lực thủy tĩnh chi phối bởi quá trình đối lưu và phân tán gây ra bởi việc khai thác nước quá mức.

Tù khóa: Nước mặn, cơ chế xâm nhập, Đồng bằng Sông Hồng. 